\title{
Re-inventing Womanhood: Transcending the Depressing Home Spaces and Fragmented Familial Ties in Alice Walker's The Color Purple and Chimamanda Adichie's Purple Hibiscus
}

\author{
Elly Makari ${ }^{1 *}$, Wasena Antony ${ }^{2}$, Busolo Beatrice
}

\author{
${ }^{1}$ Catholic University of Eastern Africa (CUEA); P. O. Box 908-30100, Eldoret, Kenya \\ ${ }^{2}$ Kenyatta University \\ ${ }^{3}$ Lecturer, Faculty of Arts and Social Sciences, Pwani University, P. O. Box 195-80108 Kilifi, Kenya
}

DOI: $10.36347 /$ sjahss.2020.v08i09.003

| Received: 24.08.2020 | Accepted: 01.09.2020 | Published: 04.09.2020

*Corresponding author: Elly Makari

Abstract

Review Article

A woman's immediate environment determines her course of life. This is more so when both enduring practices of culture and race seem to conspire to restrict a woman's possibilities of mapping her vision and maneuvering through the day-to-day challenges. In this study, we explore how Alice Walker's The Color Purple and Chimamanda Adichie's Purple Hibiscus portray the deceptive systems of inequality as espoused in the depressing home spaces. The illusory familial ties are revealed for what they really are: ties that bind the woman to servitude. The two writers suggest a need for a new gender consciousness that will give space to a new woman to unfurl. The two novels converge at the point of imagining a refashioned woman who, having festered within walls of patriarchal reign, lets the male excesses to implode and out of the patriarchal smithereens, emerges a majestic woman. Locating its search in the theoretical strain of Ogundipe-Leslie's Stiwanism, this study confirms the two texts as formidable proposals for a possible independent vision of a black woman.

Keywords: Women Dignity, Home Space, Familial Ties, Alice Walker, Chimamanda Adichie.

Copyright @ 2020: This is an open-access article distributed under the terms of the Creative Commons Attribution license which permits unrestricted use, distribution, and reproduction in any medium for non-commercial use (NonCommercial, or CC-BY-NC) provided the original author and source are credited.

\section{INTRODUCTION}

The Color Purple and Purple Hibiscus reveal the constructed nature of sexual relations and the basis of their tilting in favour of the men. It is generally admitted that black women are uniquely situated in that they stand at a focal point where two powerful and prevalent systems of oppression intersect: race and gender. The study recognizes that numerous aspects contribute to the suffering of women. The purpose of this paper is to explore the quest for the dignity of women with highlights of impediments like the depressing home space and the broken familial ties, which negate the aspirations of women in a traditional set-up. The first section analyses a home as a depressing space and how broken family ties limit, even more, women's dreams. The second part expounds on women's stoic choice of acceptance of their fate by transcending the misfortunes and understanding a possible mission to awaken themselves.

\section{The Quest for the Dignity of a Woman}

Akoété Amouzou believes that, in Africa and elsewhere, most societies are patriarchal in essence and these societies are crippled by many impediments, which contribute to their tragic underdevelopment. This situation has been a topical issue for the entire world since the end of the second war [1]. Alice Walker and Chimamanda Adichie's texts are in many ways novels about society and its intricacies, as they explore one's worth and the tiers of social order. Women, in this case, find themselves at the exterior end of such a structure, which is the major trigger to their stressful existence in society. The two writers use fantasy as a way of representing the horrors of a repressive society. Alice Walker and Chimamanda Adichie in their works bear witness to atrocities against women and the possible ways of attaining women's dignity. Azuike Maureen Amaka feels that Adichie's novels are populated by psychopaths, rapists, religious fanatics and ruthless rulers all of whom terrorize women [2]. She, therefore, uses her novels as instruments of self-discovery and healing for the abused women in Nigeria who may have 
undergone some traumatic experiences in their marriages.

As female characters gain their position in society, they too wish to accomplish their quest for the dignity of women. Stakahashi reveals that Molara Ogundipe calls on women to be at the forefront, as seen in several characters in The Color Purple and Purple Hibiscus, in educating the society about the rights and responsibilities of a modern nation, if a woman strives to be independent [3]. Thus, through their journeys, women begin as individuals, then they are bound by their experiences such that they can pursue their interests as a unit. In the process of pursuing their dignity, women are initiated from naive and oversubmissive characters into the enlightened "beings". Their journey is the journey of inspiration to every woman and serves as a source of hope to the disillusioned in society.

\section{Home as a Depressing Space}

Molara Ogundipe-Leslie poses a question; does the female writer have any particular commitment as a female? [4]. For instance, to challenge the men domination in society and making people believe in the independent humanity of women. Marriage becomes the subject of discussion, place of women's selfhood, dissolution into the men. How they get new titles to "Mrs." What are these positions of power; is it men or women in power? There is a need to demystify women and their position in homes, challenging the notion that men are the owners of the home. One would look at a home, which position does have power, if it is in politics, who is in power? All comes to the decision making in the home and the society: is it a woman's or a man's opinion that counts? In Purple Hibiscus, for instance, Eugene's opinion is always right. This is equally seen in The Color Purple where equally, Celie has no say in the forced marriage.

A home is made up of a family. Family life, in this case, has many debacles that oppressively dictate the lives of women in both The Color Purple and Purple Hibiscus texts. To borrow Antonio Gramsci's concept of hegemony, a home becomes a hegemonic environment that is used to suppress liberty and the development of women's identity. At the start of The Color Purple and Purple Hibiscus, we immediately discern that the stressful conditions of being a woman are further complicated by demeaning cultural practices falsely portrayed as natural. Women subjugation is thus constructed. Ideally, a home is meant to be a well for the family in terms of wealth. But for women in Color Purple, home has become a space of agony, full of stressful encounters as seen when Alfonso comes in as a foster-father to Celie and Nettie.

Purple Hibiscus shows how Kambili hails from a civilized and wealthy family, but contrary to the expectations, their home becomes a den of stress and trauma because of their father's, Papa Eugene's, tyrannical tendencies. Oge A. Ikediugwu and Kola Eke agree that Papa subjects the members of his household to constant beatings, harassments and inflictions [5]. Therefore, in both texts the family and home as whole triggers, many unpleasant memories of most of the women covered. The home set-up in The Color Purple forms a very ripe ground for perpetuating sexual abuse that is mostly directed on young innocent girls. As per the African culture, wife inheritance happens when a woman loses her husbands and a close relative comes in the family to take care of the widow and the orphaned children. This means that Alfonso most probably is related to Celie's late father and a lot is expected from him in terms of supporting this family.

Celie exposes her sexual molestation at the hands of her foster-father Alfonso at the age of fourteen. He a little nervous too, but I don't know why, till he grab me up tween his legs.... It hurt me, you know, I say. I was just going fourteen. I never even thought men having nothing down there so big. It scare me just to see it [6].

That a young unsuspecting girl should be seized and ravished to satiate the wild appetite of a sexual pervert shows how women are objectified. Celie would live with the trauma of the attack as the wounds of such dehumanizing treatment would not be easily healed. Simone de Beauvoir, in The Second Sex, interrogates the situation of women noting that it prevents them from exploring the world's basic problems because man is always considered the default, while a woman is seen as the 'other' [7]. After the death of her husband, depression to takes toll on her and eventually she is inherited by Alfonso, a mistake she rues later. The sight of it nearly killed her, and her second baby, also a girl, was born at this time. She continued to fix her husband's plate at mealtimes just as she had always done and was always full of talk about the plans she and her husband had made. This is what is expected of Celie when she is given away to Mr Albert by Alfonso for marriage where she is expected to take care of the orphans left by Albert's wife, Margaret.

Both men and women connive to create a world that does not value the life of a girl-child and gives very little space for their growth and exploration of the available opportunities in society. Celie's lamentation of inaction by society reveals the dire situation that women are in as every aspect lies against their progress in the home space and the society as a whole. This is contrary to Bowlby's expectation that children desire to be around caregivers for safety and a chance for exploration [8]. The feeling is that those that are supported attach themselves to virtues but those left alone develop into indecisive, avoidant, or jumbled teenagers. Kambili's situation is best compared to Celie's, as experience which creates timidity and 
apprehension in her. She says, "He don't say anything. He set there by the bed holding her hand an cryin, talking bout don't leave me, don't go" [6]. This kind of surrounding is very volatile and cannot support proper growth and development. Celie and Kambili are put through indignities - violence and molestation. J. Rodgers Kurtz states in his work,

Growing up in this well-heeled but terrifying setting, Kambili is a nervous wreck, never knowing when to expect another outburst of physical abuse from her father. There are several horrifying instances of Eugene's violence against the children and their mother, and the family develops a range of coping mechanisms for dealing with this pathological home environment [9].

When Sofia and Celie engage in a conversation, she highlights how society expects women to carry themselves. She says:

To tell the truth, you remind me of my mama. She under my daddy foot. Anything he say, goes. She never say nothing back. She never stand up for herself. Try to make a little half stand sometime for the children but always backfire [6].

This is what the society expects the women to behave and any woman who tries otherwise is labelled and called heart-breaking names meant to cut her to size. This is what happens to Shug Avery as she is called all sorts of demeaning names by the preacher as a measure of curtailing all other women who might think otherwise. She does not mind all these but goes ahead to live and empower other women's lives positively. Alice Walker strives to create a self-worth woman which is in line with Akoété Amouzou's sentiments on Nwapa's fiction stating that it creates a seemingly decent society for women.

It is a society respectful of its women. She openly confronts the issues of gender and the distribution of power by the patriarchal society. She moves her female characters from the innocent and helpless position to a state of self-empowerment and authority throughout her texts [1].

Female sexuality is used to control ethnic lineage, represent the values of religion and rape is used as a military tactic in some war-torn areas. In The Color Purple, Shug Avery is such a woman that bears the wrath of the society when she creates her perspective of life that other women fear to explore. She uses her sexuality to gain power in society as she moves with any sexual partner that she wishes to both men and women. She too falls in love with Celie whom she helps uplift her self-esteem and sense of sexuality." All the men's eyes glued to Shug's bosom [6]. Celie tells of some of the names that the preacher calls Shug. "Talk bout slut, hussy, heifer and streetcleaner" [6]. The experience of being a woman is rich with stories of misogyny, harassment, and violence. Women look at the world around them and feel like they are in prison [6]. In the same line, Guo Deyan feels that "In The Color Purple, Walker aims at illustrating the truth that in the patriarchal culture, women can define themselves only through the kind of friendship and sympathy developed with other women" [10].

Chimamanda Adichie opens her text, Purple Hibiscus, with Kambili painting a sorry state of affairs in a wealthy family that is conditioned on the dictatorship and brutality of the head of the family, Papa Eugene [11]. All these encounters rest on the woman of the house, Beatrice, who calmly comes in and starts to pick the pieces with her bare hands. She is not supposed to show any resentment to the mistreatment of her son by Papa Eugene. Kambili says, "She stared at the figurines pieces on the floor and then knelt and started to pick them up with her bare hands" [11]. 7). This action shows how she is rendered powerless in the home and she no position to question anything be it right or wrong. Therefore, there is an urgent need to change such a situation in society and that is why Walker and Adichie use their writing to bring all these challenges to the fore. Georgiads Mboya Kivai sums up this by saying,

Adichie's writing is an effort to voice the internal knowledge and needs of women in a way that challenges the status quo. She reworks earlier images of African women projected by patriarchal order and figures female characters as speaking subjects in Purple Hibiscus and Half of a Yellow Sun [12].

In Purple Hibiscus, a home is associated with a lot of tension and fear among the family members. Close to these restrictions is Kivai's feeling that,

The basic pillar of the patriarchal power within the African context is the silencing and suppression of women including the control of their bodies. To empower the African woman, Adichie crafts stories with female subjects pursuing female interests. She also structures her narratives to contest the male power with its violent manifestations. Her exercise is an invention of gender power discourse that serves to inspire the female struggle against male domination [12].

Papa Eugene's family is under constant fear and anxiety to understand to an extent that no conversation takes place except in a mechanical way. Two bottles of the newest juice are brought for testing 
where every member of the family is forced to praise the products except Jaja, who keeps quiet, bringing in more tension. "Have you nothing to say, gbo Jaja?" [11]. This bold move by Jaja sets in nervous conditions and fear as no one ever thought of breaking the law set by Papa Eugene.

Kambili and her brother, Jaja, are forced to take very hot foodstuffs in the name of love and sharing. Kambili says:

I sat at my bedroom window after I changed; the cashew tree was so close I could reach out and pluck a leaf if it were not for the silvercolored crisscross of mosquito netting [11].

Such kind of a home cannot give anyone peace and tranquillity required to develop self-esteem and a sense of independence. The association with other members of the society is limited to the extent that there is a driver, Kevin, employed to drive both Jaja and Kambili to school and back every day. "Before, our driver, Kevin, would pick me up first at Daughters of the Immaculate Heart, and then we would drive over to get Jaja at St. Nicholas" [11], reveals how other classmates like Chinwe feel about Kambili. "Chinwe just wants you to talk to her first," Ezinne whispered. "You know, she started calling you backward snob because you do not talk to anybody" [11]. Papa Eugene's children, Jaja and Kambili, cannot even hold a conversation with their cousins.

A home with restrictions majorly contributes to low confidence among the members that hail from these families. Kambili and Jaja have to find some time away from scheduled life to at least release their stress. Kambili says, "We always soaked tiny sections of fabric in the foamy water first to check if the colors would run, although we knew they would not, we wanted to spend every minute of half hour Papa allocated to uniform washing" [11]. Schedules are the order of the day in this home as both Jaja and Kambili have written up schedules, and they wonder if the anticipated baby would also have the same. Kambili says, "I wondered when Papa would draw up a schedule for the baby, my new brother, if he would do it right after the baby was born or wait until he was a toddler" [11]. This kind of environment hampers the psychological growth and development of children who later will have no creative minds, confidence in their abilities and poor decision-making.

The family's life becomes a cycle of violence. Marriage becomes a mountain that women constantly attempt climbing. This is best put by Molara OgundipeLeslie's statement that, "Oppression at the matrimonial level as one of the mountains that keep the African women in subordination" [13]. This creates naivety and being naive is a fertile ground that propagates these vices as women like Mama Beatrice fail to stamp authority in the advent of violence in their homes. She is forced to endure all the challenges of carrying her pregnancy against her will for the sake of her husband's reputation at the church. "Let me stay in the car and wait, biko," Mama said leaning against the Mercedes. I feel vomit in my throat" [11]. When Papa Eugene asks her if she needed to stay in the car, she opts to follow him to the priest's house. Kivai admits that,

Papa's word is final and he disregards the wife's feelings and thus Beatrice hangs at the periphery of Papa's world. Despite being unwell she is compelled to go with the rest to the priest's house [12].

A lot of violence and inhospitable homes make women who are overly submissive like Beatrice fail to make proper decisions, even in the times of their pains and suffering. Ezinne tells her, "Maybe after school you should stop running off like that and walk with us to the gate" [11]. All these kinds of mannerisms have been bred by the volatile environment in their home something that is ironic as one would expect that such a civilized home most probably understands the need for fair treatment and respect for human rights. Kambili narrates how one time she heard the heavy thuds in their parents' bedroom. "I imagined the door had got stuck and Papa was trying to open it" [11]. Both Jaja and Kambili see a lot of blood on the floor and their mother never came back that evening because she had been admitted to the hospital. Kivai notes that,

Mama is always captured by the narrator as having swollen eyes or face in tears, a jagged scar or bleeding from the violent assaults of her husband. The family is always experiencing nervous moments due to paternal brutality. They are silent or talk with suppressed voices [12].

In this case, violence that is perpetuated by chauvinistic elements is aimed at controlling women and rendering them docile only depending on men's decisions whether good or bad. The woman who was battered then will feel sorry for the man and recommit to him in a fantasized hope that the abuse will not happen again (Albert and Elaine Borchard Foundation, Dr Ezekiel R. and Edna Watts Dumke Foundation). Therefore, it is ridiculous that later on that evening the family is made to recite different novenas for their mother's forgiveness. And on Sunday, the first Sunday of Trinity, we stayed back after mass and started the novenas [11].

But this cycle of abuse does not stop as it becomes even worse when Papa Eugene pours hot water on Kambili's feet for staying with their heathen grandfather, Papa Nnukwu. "He lowered the kettle into the tub, tilted it toward my feet. He poured the hot water on my feet, slowly, as if he were conducting an 
experiment and wanted to see what would happen" [11]. Women look at themselves as helpless and hopeless human beings who cannot do anything without the help of men. The family set up and home setting has been made in such a way that women are dependent on men to an extent that they feel that their life cannot be complete without men. Though it is painful for one's husband to be arrested maliciously, the desperation that Yewande portrays is too much before Papa Eugene. This indicates that women are problems for themselves and their cause [11].

Society expects women to give birth to as many children as possible not two as it is with Papa Eugene and Mama Beatrice. The members of Umunna sent people to Papa Eugene to urge him to get another wife that would give birth to children. So many women were ready to give their daughters so that many sons would be born in Papa Eugene's home. This rocks women's lives as they have been socialized to accept this kind of demeaning practice where their main reason to be in a marriage is to give birth to as many children as they can [11]. A home becomes a suffocated space as women themselves allow themselves to be objectified by men and be made second wives and so on.

Not all the families and homes presented in the Purple Hibiscus undergo culture and patriarchal instigated suffering, there are a few that have success stories. As Amaka talks to Kambili she says, "I listen mostly to indigenous musicians [11]. Aunty Ifeoma has given her children enough freedom, and they can explore what is around them so long as it is not bad. In her family, Aunty Ifeoma supports all her children; Amaka, Obiora, and Chima are all enthusiastic. Ade Coker's family is presented as a happy family that is anchored in love and understanding. This is why when Coker is arrested, she gets stressed and asks Papa Eugene to help get her husband from prison. This is a family that exhibits a lot of love as Ade and his wife, Yewande always moves together happily [11]. This is shown by Mama Beatrice's statement as she calls Jaja and Kambili to pass their greetings to Ade and Yewande on their way to their rural home for the Christmas holiday. Amaka has enough freedom that enables her to explore her passion for drawing, unlike Jaja and Kambili that have scheduled life that hampers their creativity and sense of exploration. Samuel and Corrine and Aunty Ifeoma's homes and families in The Color Purple and Purple Hibiscus respectively, have a very healthy interaction full of respect; free, but meaningful speeches are happy families and homes that Walker and Adichie envision.

\section{Fragmented Familial Ties, and the Cycle of Stress}

Alice Walker and Chimamanda Adichie have explored familial space - a central trope in their works to show the narrators' physical and psychological journeys as they walk through family life that has many hurdles to handle. Fragmented familial ties result in bad parenting styles that have many dire bearings on the psychological and physical development of children in the family. A broken family because of conflicts between a husband and a wife especially because of violence and other types of brutalities weighs down on self-esteem and the sense of belonging to both boys and girls that are victims in this scenario. And this is intimated by Kivai who implies through her assertion that.

The opening lines of Purple Hibiscus signal a threat to continued co-existence of the family members because of lack of free space. The home is in turmoil and things are about to fall apart. It means the center symbolized by the paternal authority cannot hold anymore and further suggests that several centers of authority are necessary. It is in the other center(s) where the characters living in Eugene's family enjoy freedom [12].

In The Color Purple and Purple Hibiscus, it is entirely an implied aspect that affects some families through the problems that may not be directly linked to broken family ties. Separation of family members from other relatives, for instance, in The Color Purple can be implied as a manifestation of broken family ties. Picking of Olivia and Adam from Celie and Nettie's escape are perfect examples of what contributes to broken family ties and the consequences of parenting styles.

Broken family ties pose many threats to the happiness of members of the family especially women and children. This is a problem affecting many families that exist in the societies of The Color Purple. A child's tie with his or biological parents is the most "intimate" and "closest" to his being. She tells Celie of her two lost babies; Olivia and Adam, who she coincidentally stays with when she joins Samuel and Corrine on their missionary work in West Africa among the Olinka people. It is worth noting that men have taken the racial and colonial ideologies of segmenting families, a concept that White Masters used to oppress the Blacks as a measure of controlling them. This is in addition to the extra-marital affairs that Mr Albert has with Shug Avery." Mr_be gone all night Saturday, all night Sunday and most all Monday" [6]. In addition to her misery, she has been torn apart with her babies who are taken away from her at a very young age. She meets a woman at the store with a baby girl exactly as Olivia, but they lie to her that she was Pauline. She had been taken away from her at the age of two months. Celie says:

I calm down from the wagon and I follow Olivia and her new mammy into a store. I watch her run her hand long side the counter, like she ain't interested in nothing [6]. 
This is painful to Celie to see her daughter tagged along with a strange woman. She is helpless because the legal systems are not in favor of African Americans. African American women have been disempowered socially and economically, which makes it hard for them to access legal services to redress some of their problems. It is highly likely that her inadequate formal education does not give her enough intelligence of reasoning out the best course of action to take against this inhuman act. Celie is distressed in that she does not know what is going to happen to her children born out of incest. She tells Shug that they might be dunces. She does not know how they will react if they are told this terrible news. But the discovery of these letters by Shug Avery in the boot is the beginning of a re-integration of Celie and Nettie's broken ties. This evokes a lot of hope and it strengthens their spirit to fight on.

Sofia declines to work as a servant for white masters; Miss Millie and her husband. When the mayor insists, she beats him up and this results in her arrest and imprisonment for twelve years. She faces a lot of suffering in the pretense of the reduced sentence of being taken to Miss Millie's home as a house help. This is against her will and it is meant to torture her even further by the manipulated court systems [6]. She has to take care of a racist family whose children are extremely violent towards her. Sofia narrates all these traumatic experiences that she goes through besides the stress of being away from her children and husband. She is given a little storeroom up under the house as her shelter. They make sure her social life is in shambles as they deny her any chance of seeing her children. Though her sentence is reduced by half for good behavior, she has missed her marriage life and her children's growth. Sunitha Diwakar portrays Sofia's resilience by stating that, "Although brutally bruised, mutilated and suppressed Sofia stands as stark contrast to Celie in her efforts to put up with the maledominated world" [14]. Shug Avery also in The Color Purple is raised by a single mother, family and later taken to Memphis to stay with her unmarried aunt that moves all kinds of men, drinks gin and works in a brothel.

Parenting styles are very important aspects that shape the kind of family ties that exist within a given society. Art Rolinck and Rob Grunewald underscore this assertion by intimating that,

If a child has support for healthy development in families and communities during the first few years of life, he or she is more likely to succeed in school and to contribute to society as an adult. Responsive and consistent parenting is an essential ingredient for healthy child development [15].

Therefore, a given style of parenting greatly contributes to the way one looks at life, especially in terms of gender orientation. Women are made to believe that at a certain age, they should get married, have children and have a successful family. This makes women worry so much about their womanhood, children, husband, and family. "And I have nothing of my own" [6]. Samiha Saddiqua feels that children raised by two biological parents do better in life as individuals, irrespective of their economic conditions [16].

Alice Walker and Chimamanda Adichie's portrayal of many families in their texts, this argument is disputable in that some families that have both biological parents do not do well at all. But a few that have two complete foster parents, mother, and father, successfully raise their children. In The Color Purple, for instance, Mr Albert's family does not bring up their children well at all because of too much domestic violence that leads to the murder of the women in this family. Mr Albert says, "Wives is like children. You have to let 'em know who got upper hand. Nothing can do that better than a good sound beating" [6].

In contrast, Samuel and Corrine's marriage that is composed of adopted children, Olivia and Adam, is successful in that there is adequate support morally, spiritually and financially towards the well-being of the entire family. It is a family that is based on understanding and Nettie proves this when she shows how she was peaceful. A strong and balanced twoparent family ideally ensures that all the basic needs of the family. Such a family develops a sense of belonging and security in individuals of all kinds. There is a happiness that flows through the family." I stroked his dear head and face and I called him darling and dear..." [6].

Celie and Nettie's mother breaks down in distress when her husband, a successful Black American business person, is lynched by White extremists because of business competition. His death leaves the family in fragments and vulnerable and men like Alfonso take advantage of this situation. This is where the sexual molestation is aggravated and Celie suffers a lot while Nettie is forced into exile. This kind of parenting and family setup is very stressful for young girls like Celie and sister, Nettie [6]. They become victims of the circumstance, and they suffer a forced separation that tortures them psychologically. Deborah L. Ruf thus holds an opinion that,

When children's parents are not together, the children are likely to feel less secure and, sadly, less important. When children have one parent who isn't very involved at all (or is completely absent), they are left with the question of their value. "If I am not important enough to have my parent around and involved in my life, what's wrong with me? Why doesn't he/she care about me?" [17]. 
Eugene, the head of the family in Purple Hibiscus, is a wealthy entrepreneur but suppresses and subjugates his wife and children. Eugene's family is an example of a complete family that has all biological parents present in the lives of their children. But there is a lot of disintegration as Papa Eugene makes the environment very tense and frightening for his wife and children; Jaja and Kambili. The two parents are supposed to develop a sense of belonging and security in their children, but Eugene does the opposite by psychologically and physically molesting everyone in his family. It takes a lot of force from Aunty Ifeoma for Papa Eugene to allow Jaja and Kambili to go to Nsukka and meet the likes of Father Amadi. This is the place the reawakens their consciousness and builds their selfesteem and confidence to say no to suppression. In the opinion of Nilima Meher, Nsukka's environment, Ifeoma, Father Amadi and the children of Ifeoma were mentors for Jaja and Kambili under whose guardianship they attain their maturity [18]. Her crafting of this family is in agreement with Samiha Saddiqua sentiments that the success means that family ties build a sense of responsibility not only in childhood but also make individuals more emotionally secure and ready in adulthood to take up responsibility for their own families and children that other marriage substitutes only help dodge [16]. This can be seen in how Aunty Ifeoma takes up the responsibility of moulding her sons and daughter. This is what Aunty Ifeoma passes to Kambili and Jaja when they visit her at Nsukka. Therefore, this is a story of a successful widow who works hard, an active unionist and a lecturer that moves to America to look for greener pastures.

From the explanations above, it is clear that parenting style and fragmentations within families result in many problems that affect women children greatly. Todd Peterson's solution is, "Stop the fragmentation of adult couples and we solve the fragmentation of families. Thus, rather than lamenting the tragedy of fragmented children, fragmented parenting, and fragmented resources, let's fix the adult problem" [19]. Alice Work and Chimamanda Adichie thus call for a cohesive family unit and proper parenting styles that give room for proper growth and development of children and free exploration of women in the society. Samuel and Corrine's and Jack and Odessa's families in The Color Purple are examples of ideal families that Alice Walker advocates for. They are built around love and respect that makes them experience a lot of happiness. This is the same view that Chimamanda Adichie holds when she shows Ade Coker and Yewande and Aunty Ifeoma's families in Purple Hibiscus which show a lot of love and understanding among the family members. Therefore, these families most probably are built-in authoritative parenting styles that monitor and discipline their members fairly, while being supportive at the same time.

\section{Women's Stoicism}

Women undertake creative measures to alleviate their terrible situations in society. Alice Walker and Chimamanda Adichie take an initiative through their writings to push for a gender-balanced society. The Color Purple and Purple Hibiscus are a social protest to fight against gender corruption in a culturalized and conservative society. In one of her works, Simone de Beauvoir's The Second Sex interrogates the situation of women noting that it prevents them from exploring the world's basic problems because man is always considered the default, while a woman is seen as the 'other' [7]. As the undervalued sex, women are cruelly treated by men and the racial masters, the evils of a patriarchal world and the dark side of male nature are fully presented. Julie Bindel states that women have developed certain skills because of men's tyranny [20]. This can be compared to Mears' analysis of Amaka in one is enough?

Therefore, One is Enough emphasizes the decision of one woman, Amaka, who decides to take responsibility for her future by leaving her rural village, by divorcing her husband, and by moving to Lagos. Six years of a childless marriage was enough for her. After arriving in Lagos, Amaka learns the conniving methods of achieving success as a businesswoman. She decides never to marry again even though she does have children. She concludes that women can be happy, fulfilled, and successful without being married as long as they have their own money [21].

When Celie grows up psychologically and realizes what she has entertained all along, she is very bitter and feels like killing Mr Albert. But Shug Avery reminds her that if she killed Albert it would be a disaster for her and that she should remember that she has a sister in Africa who loves her so much and needs her. She feels bad for what Mr Albert has done to her by hiding Nettie's letters. She does not want Celie to go through what Sofia has gone through in prison and the hands of Miss. Eleanor Jane, Miss Millie's daughter does not let Sofia to be blamed for what she has not done. Billy wants her blamed for causing injuries to his leg, which is not true because he hurts himself trying to kick Sofia just because she is a black servant." Little girl pipe up. Millie, who now sees sense and even suggests allowing Sofia to visit her family occasionally, Sofia decides to take care of Mary Agnes' daughter so that she could concentrate on her singing career." Go on sing, say, I will look after this one till you come back" [6].

Olivia decides to mentor Tashi to open her mind to explore her abilities. She intends to find out why Tashi cannot be taken to school and why Olinka people do not believe in educating girls. Together with Corrine and Samuel, they manage to convince Tashi's 
parents to take her to school. She looks at Olinkas as the White American who did not want African Americans to get educated. She teaches Tashi after her household chores. Nettie says: "Oh, she's sharp, Celie. At the end of the day, when Tashi can get away from all the chores her mother assigns her, she and Olivia secret themselves in my hut and everything Olivia has learned she shares with Tashi. To Olivia right now Tashi alone is Africa" [6].

Shug Avery chooses whom to stay with and to what level, she feels the relationship is working or not. She drinks; she fights and loves men just like Shug Avery does. She felt painful when $\mathrm{Mr}$ Albert failed to stand up for her, but instead went ahead to marry Annie Julia." Then she says. She says: I went to stay with my mama wild sister in Memphis. She drinks, she fights, she love mens to death. She works in a roadhouse" [6]. Annie Julia decides to explore her sexuality after she gets in a marriage that does not work with Albert. She feels very bitter because it is her schoolmate; Shug Avery takes her man, Albert. Even though this leads to her death, but she at least goes against the societal grain to be happy. She tells Harpo, "When you free, me and the baby be waiting" [6].

Sofia reveals to Celie how she has had to fight chauvinists beginning with her father, brothers, cousins, and uncles who try to infringe on her rights. She vows not to let any man molest her, for she promises to kill him before he does it. She says, "All my life I had to fight. I had to fight my daddy. I had to fight my brothers. I had to fight my cousins and my uncles" [6]. She is a liberated woman who does not wish what happened to her mother to happen to her. When she looks at Celie's life, she remembers the mistreatment that her mother faced in the hands of her father. Celie wishes to be like Sofia in that when Harpo tries to beat her, she seriously beats him up leaving his face a mess of bruises." Next time us see Harpo his face a mess of bruises" [6]. She shows that the growing society no longer needs violence to solve domestic problems, but a peaceful way of understanding the weaknesses and strengths of each one in the family.

As times change, women decide to control their stakes in social and economic spheres by creating relevant avenues that earn them a living. This is the best way they walk through a highly oppressive society: self-empowerment. O. A. Akanmode agrees with this notion stating that an individual must empower herself first then others [22]. Celie empowers herself first before joining Sofia to begin quilt making craft that makes them busy and economically independent. To Harpo, Sofia is supposed to be at home and not at the bar at night. Guo Deyan shows how he hopes to dominate Sofia and wants her to do as what he says [10]. However, Harpo's efforts are fruitless since Sofia's spirits will not allow her to be as servile as Celie. She deserts Harpo and leaves with the children
[6]. Harpo who is supposed to do all this work is emasculated and made to like the kitchen so much that he keeps on eating. No matter what happening now. This is a direct mockery to the chauvinists because of how they treat women. Therefore, music is a channel of advocating for women's rights and the possible preference that would improve their wellbeing in society. Singers like Kelly Clarkson, in her song "Miss Independent", Destiny's Child in "Independent Women" and Ne-Yo in "Miss Independent", among other artists, create songs that center on women empowerment and encourage more women to emulate such women for a better society. "Miss Celie's Song" is a song that is after lifting her spirits and self-worth. This song appreciates Celie and encouraging her not to count on any man again. Mary Agnes' song, "They Calls Me Yellow" is a perfect example of rap against racism and sexism.

The mission of women in The Color Purple is to achieve complementarity between female and male genders. Ogundipe-Leslie, in her Stiwanism, calls on women to take a personal active interest in their society. Women must not sit back and allow or expect men to do social advocacy on their behalf [3]. Women like Shug are on a mission to end patriarchy, and this is why she is ready to sacrifice her career just to make sure Mr Albert never touches Celie violently. She says, "I won't leave, she say, until I know Albert won't even think about beating you" [6]. Jack, who is Odessa's husband has no issue, especially around the oppression of women in his family. This is the same thing with Samuel and Corrine's family that is largely peaceful. Harpo and his father, $\mathrm{Mr}$ Albert eventually begin to appreciate women and never engage in acts that hurt women psychologically or even physically. Thus, women empathize with each other's situation and that is why they do anything to end their suffering. She yearns for a world where women stand for each other and bring on board men to understand the need for a mutually cohesive society." Pretty soon it be time for Shug to go..." [6]. It is clear now that there is a need for a mutual co-operation between men and women. Therefore, the mission is being achieved where cooperation between men and women can be seen. This a good sign that the future is bright and there is a possibility of minimizing gender biases in society.

Alice Walker is forced to delve into the racial politics in America that doubles up as a source of pain to the African American women. Sunitha Diwakar portrays this commitment by indicating that Walker is not just concerned about women, but is committed to the survival and wholeness of the entire community [14]. This goes along with Ogundipe-Leslie's call for women to educate other women about the rights and responsibilities of a modern nation if a woman strives to be an independent individual. Sofia beats up the Mayor, and she is arrested just because she is black Miss. She is imprisoned for twelve years, made to do menial labor under very poor working conditions." They put Sofia to 
work in the prison laundry" [6]. In Purple Hibiscus, Chimamanda Adichie calls on women to be responsible and get the right strategies to uplift themselves in society. Amaka provokes Kambili by the way she articulates herself and understands what she wants. She listens to whatever music she likes, puts on earrings and wears lipstick. She does not allow public opinion; puts on a pair of shorts, rubbing her hands over the front of her T-shirt. Amaka remarks that she knew Kambili and other teenagers were into American Pop and that they did not listen to culturally conscious music [11]. Thus, there is increased awareness among women as they grow and try to change the tide that sweeps against them and their endeavors in society. They venture into a variety of careers that fit them against the societal sexism norms that keep some careers for men and some for women.

When we look at the case of Aunty Philipa, she is extremely sharp, and she specializes in botany and does many experiments. The same sentiments are echoed by Akoété Amouzou who believes it is a fact that her female characters accept themselves as women, but new women, different from the stereotypes with negative images that the reader is familiar with in maleauthored texts [1]. This beats all the odds as women have always been placed in the home. Beatrice is a good example of what a woman should be, home career and taking care of the husband. But Philipa and Ifeoma go beyond this as they lecture at the Nigeria University of Nsukka. Aunty Ifeoma works in an office at the Institute of African Studies." Aunty Ifeoma pointed at a building next to the school, the Institute of African Studies, where her office was and where she taught most of her classes" [11]. Women can no longer be contained in the home setting. They can own property the way Ifeoma does. She owns a car. "The street she turned into was steep, and she switched the ignition off and let the car roll, loose bolts rattling" [11]. Therefore, a lot has changed in terms of property ownership and every gender can acquire property without being discriminated based on their gender. Women's solidarity, in this case, makes them acquire a lot of ground in terms of their transformation. This why Kivai's feeling is that in Adichie's novels constitute cases of women coming together to challenge the effects of patriarchy or to aid one another to overcome male-created misfortunes are notable [12].

Carmon Daniel acknowledges that women's educational achievements have positive ripple effects within the family and across generations [23]. In agreement with the assertion is Kivai who admits that women's education is a strong socialization tool used by women in Adichie's novels to fight insubordination and oppression [12]. The note is that Aunty Ifeoma and Philipa are educated and liberated. Aunty Ifeoma's empowerment through education is an indication of how a society can be modified. Aunty Ifeoma changes Kambili and Jaja's perspective in life. They are included in all the activities that Aunty Ifeoma's children participate in like washing, fetching water and preparing dishes. Kambili says, "Aunty Ifeoma included Jaja and me in the plate-washing schedule, and after I washed the garri-encrusted lunch plates" [11]. They talk about hairstyles and other teenage topics that Kambili has never had an opportunity to talk about. She says, "I wanted to talk with them, to laugh with them so much that I would start to jump up and down in one place the way they did, but my lips held stubbornly together. I did not want to stutter, so I started to cough and then ran out and into the toilet" [11]. Jaja's real name is Chukwuka, but he is nicknamed Jaja as the words he would pronounce at his baby-stage were "ja-ja". Aunty Ifeoma and Mama Beatrice find it appropriate to give him this name after Jaja of Opobo a defiant King that was against British domination in trade. It is a symbolic name that later lives to its expectation as his engineered constructive defiance leads to the eventual fall of Papa Eugene, the patriarch. Aunty Ifeoma talks about how important defiance can be at times when all other means seem not to work. This a true observation as it helps shape the destinies of Philipa, Ifeoma, Mama Beatrice and other like-minded people who defy the order of the day to drive their gender equality gospel.

The voice of a woman and her imitative shapes the society in the desired way. Ogundipe-Leslie in her Stiwanism, calls on women to take a personal active interest in their society. Women must not sit back and allow or expect men to do social advocacy on their behalf [3]. This can be witnessed in the efforts taken by Aunty Ifeoma and it seems to bear fruit in the society as her sons and daughter portray a new generation that understands the need for equality and complementarity. This is becoming an inspiration to Jaja and Kambili who begin to take charge of their destinies. Women exhibit their abilities and their progressive ideologies through working hard whenever they are. Mama Joe has a salon shed on the Ogige market where she plaits women's hair. This is the same place Aunty Ifeoma did her plaiting. Father Amadi takes Kambili to the same salon. Mama Joe praises and acknowledges Aunty Ifeoma's effort in bringing up her three children; Amaka, Obiora, and Chima. Indeed, Aunty Ifeoma is an epitome of a strong visionary woman who gets things done to better her family's life. Mama Joe doubles as a snail trader and a hairdresser at ago. This is a very encouraging scenario and it helps to inspire other women who do plaiting here. Kambili remarks, "She was on the last cornrow when a woman walked up to her and asked to see the snails" [11]. Aunty Ifeoma writes about her two jobs that she obtains in America: one at a community college and the other at a pharmacy, or drug store, as they called it. According to Kivai, this movement out of Nsukka probably to America serves to expand the space for women to challenge domination [12]. 


\section{CONCLUSION}

Women's lives in the two texts, The Color Purple and Purple Hibiscus, are narrated as shared texts. Depressing home space and broken family ties are aspects that affect women and children in Alice Walker and Chimamanda Adichie's texts. In this case, both men and women who come from abusive homes may come to view violence they encountered as normal and carry it into their relationships as grown-ups. The two writer's present women narrate their life's struggles through the situations and their eventual triumph. Kivai intimates that Adichie and her female characters form the progressive voice(s) calling for a change in the way the society treats women and the marginalized [12]. The same sentiments are held by Alice Walker's The Color Purple. Guo Deyan (2005) intimates that "After years' struggle with the overwhelmingly powerful patriarchal culture, both black men and women bring themselves to a redefinition of self in the family and the society. They discover in themselves the ability to love and to be loved and learn to embrace the selfhood, sisterhood and brotherhood" [10]. Thus, there is a need to have a society that appreciates and gives equal chances to men and women in homes, marriages and the general spheres of life. Sunitha Diwakar ends by noting that both the novels start on a very pessimistic note and end up optimistically [14]. Adichie attempts to give a voice to the African experiences and Walker continues to water her purple petunias.

\section{REFERENCES}

1. Amouzou A. 'Reconceptualizing gender in Nigerian Literature: The Dynamics of Womanist Ideology in Flora Nwapa's Fiction. Revue du CAMES-Nouvelle Série B. 2006;7(1):P26.

2. Azuike MA. Women's struggles and independence in Adichie's Purple Hibiscus and Half of a Yellow Sun. African Research Review. 2009;3(4).

3. Stakahashi. Beyond the Single Story: biographies, theory.2017.

https://beyondthesinglestory.wordpress.com/2017/1 2/13/molara-ogundipe-lesliel

4. Ogundipe-Leslie M. The female writer and her commitment. African Literature Today. 1987(15):5-13.

5. Ikediugwu OA, Eke K. Fanaticism and absurdity in chimamanda n. Adichie's purple hibiscus. Journal of the Nigeria English Studies Association (JNESA). 2013 Sep;16(2):210.

6. Walker A. The Color Purple. Harcourt Bruce Jovanovich, Publishers. New York, San Diego, London; 1982.

7. De Beauvoir S. The Second Sex (translated by Constance Borde and Sheila Malovany Chevallier). New York: Vintage Books, a Division of Random House, Inc. 2010.

8. Bowlby J, Attachment and Loss. Attachment (Pelican ed.). London: Penguin Books. 1; 1971.
9. Kurtz JR. The Intertextual Imagination in Purple Hibiscus. Ariel: A review of International English Literature, 2012; 42(2), 23-42.

10. Deyan G. A Modern Allegory of the Color Purple. International Academic Conference of Montreal (IACM), Canadian Social Sciences. 2005; 1.1 .1

11. Adichie CN. Purple Hibiscus. London: Harper Perennial; 2003.

12. Kivai MG. The Female Voice and the Future of Gender Relationships in the Nigerian Nation in Chimamanda Adichie's Purple Hibiscus and Half of a Yellow Sun. Kenyatta University; 2010.

13. Ogundipe-Leslie M. Re-creating Ourselves: African Women \& Amp; Critical Transformations. Africa Word Press; 1994.

14. Diwakar S. Symbolism of the Color "Purple" in the novels of Alice Walker's The Color Purple and Chimamanda Adichie's Purple Hibiscus. H\&S.S. Department. Mallareddy Engg. College Hyderabad. 2014; 11 (iv).

15. Rolinck A, Grunewald R. Getting Children Off to Good Starts. In Fragmented Families and Splintered Classes Why So Much Churning? What Can be Done? What Will America Come to Look Like? A Symposium. Center of the American Experiment. Building a Culture of Prosperity. 2012, 37-38.

16. Saddiqua S. Family Fragmentation: It Matters Who You Click With. 2017. Retrieved on 20 June 2019.

17. Ruf LD. Knowing What Makes Men and Women Tick. In Fragmented Families and Splintered Classes Why So Much Churning? What Can be Done? What Will America Come to Look Like? A Symposium. Center of the American Experiment. Building a Culture of Prosperity. 2012, 33-34.

18. Meher N. (Re) writing Postcolonial Bildungsroman in Chimamanda Ngozi Adichie's Purple Hibiscus. International Journal of English and Literature. 2014; 5(7), 206-210.

19. Peterson T. Losing Our Resolve to Partner. In Fragmented Families and Splintered Classes Why So Much Churning? What Can be Done? What Will America Come to Look Like? A Symposium. Center of the American Experiment. Building a Culture of Prosperity; 2012.

20. Bindel J. Gender: Obama's right, women are superior to men. Guardian News and Media Limited or its affiliated companies; 2018.

21. Mears MD. Choice and Discovery: An Analysis of Women and Culture in Flora Nwapa's Fiction. University of South Florida, Scholar Commons; 2009.

22. Akanmode OA; Snail-Sense Strategies for Women Emancipation in Promise Okekwe's Trilogy. University Wide Courses Unit, Landmark University, Omu Aran, Kwara State, Nigeria; 2017.

23. Daniel C. Women's Empowerment: Education as a Tool for Achieving Equality. The Jerusalem Post. MASHAV. 2013. 